\title{
JOAQUÍN DOMÍNGUEZ BÉCQUER Y EL RETRATO DE LISTA
}

De las relacioues de la familia Bécquer con el poeta Alberto Lista apenas sabemos la noticia escueta del aprendizaje de Gustavo Adolfo en San Diego. No obstante, como se verá en estas breves notas, la conducta generosa y desinteresada de Joaquín Domínguez Bécquer, tío del poeta, con el anciano profesor, presupone algo más que una cortés y respetuosa deferencia para con el admirado maestro.

Los cuatro últimos años de su vida representan para Lista (instalado definitivamente en su inolvidable Sevilla, calle Cervantes, número 9) el reconocimiento público de sus méritos y las postreras alegrías de su azarosa existencia. Su regreso es celebrado en cariñoso soneto por su amigo y discípulo lirancisco Rodriguez Zapata. In el plano oficial, se crea para él expresamente una cátedra en la Universidad hispalense, de cuya liacultad de Letras es nombrado Decano en I845. A los pocos meses, obtiene una canongía en la catedral y en I 847 ocupa interinamente el Rectorado de la Universidad. También ejerce las funciones de Director de la Real Academia Sevillana de Buenas Letras, cargo para el que había sido elegido en $\mathrm{I} 84 \mathrm{I}$.

Precisamente, la Academia va a ofrecernos la oportunidad de comprobar los amistosos sentimientos de los Bécquer hacia Lista. En el verano de I847, éste sufre una aparatosa caída de un carruaje en la carretera de la Algaba. Este penoso accidente, que iba a tener desastrosas con-

- secuencias meses después, le obliga a guardar cama y a apartarse de sus quchaceres habituales. Temiendo el fatal desenlace, la Acadenia acuerda, el II de febrero de I 848 , un día clespués de que el poeta hubiese firmado su testamento, costear un retrato de su Director para colocarlo en la Sala de Juntas, al mismo tiempo que los de Reinoso y Mármol, ya fallecidos. Se comunica el acuerdo a Lista, quien lo agradece por medio de Rodríguez Zapata, lamentando no hacerlo personalmente "por el mal estado de su salud". 
En principio, los académicos hicieron el encargo al pintor Escribano, pero kel señor Fiernández Espino manifestó a la Academia que el pintor del Alcázar, Don Joaquin [Domínguez] Bécquer, se ofrecía gratuitamente a hacer para la Academin el retrato del Señor Lista». Aceptó ésta complacida, y a finales de febrero el artista dio comienzo a su obra.

Deseaba la Academia dar la mayor solemnidad a la colocación de los retratos $y$, a tal fin, se pensó en una sesión pública que sirviese de homenaje y recuerdo a los retratados, contando de antemano con la asistencia del Director, que daría relevancia al acto. Iijada la fecha para el día 9 de abril, hubo de ser demorada un par de semanas, ya que a Bécquer le liabía sido imposible terminar el retrato de Lista, "por no haberle permitido todavía a éste su enfermedad prestarse a la rectificación del buston. Al fin se obtuvo su colaboración, según se desprende de una carta conservada en los archivos de la Academia, en la que, con fecha del día 7 de abril, el ilustre enfermo manifiesta que "el señor Bécquer puede pasar cuando guste a esta su casa, con tal que sea clesde las doce de la mañana hasta las dos, horas en que estoy levantädo".

La sesión pública tuvo lugar, finalmente, el clía 24 de abril, en los salones que ocupaba la Academia en el Alcázar. Presidieron las efigies de San Fernando y liernando VI, apareciendo en lugar destacado los retratos de los homenajeados: Félix José Reinoso (pintado por Escribano), Alberto Lista (pintado por Bécquer), Manuel María del Mármol y José Mraría Blanco (donados por el sobrino de este último), Francisco del Cerro y el General Pezuela. Se leyó la historia de la Academia, escrita por Juan Miguel de los Ríos, y, a continuación, Luis Segundo Huidobro leyó un discurso, "haciendo un examen crítico sobre las principales obras publicadas por cada uno de ellos, y describiendo las de la famosa Escuela literaria de Sevilla, que sostuvieron los cuatro primeros a fin del siglo pasado y principios del presente, en que tanta parte cupo a esta Academian. Rodríguez Zapata recitó después una Oda alusiva al acto, que finalizó a las dos de la tarde, hora en que se trasladaron algunos de los asistentes al domicilio de Lista, que aquel mismo día había sufrido una recaída, que le había impedido asistir al homenaje.

No esperó mucho la Academia para expresar su agradecimiento a Joaquín D. Bécquer, ya que, en la sesión ordinaria del $2 S$ de aquel mismo mes, le nombró Académico Honorario, plaza de la que el pintor tomó posesión el $\mathrm{r} 2$ de mayo siguiente. En esta fecha, su relevante personalidad era bien conocida en los medios artísticos de la ciudad, 


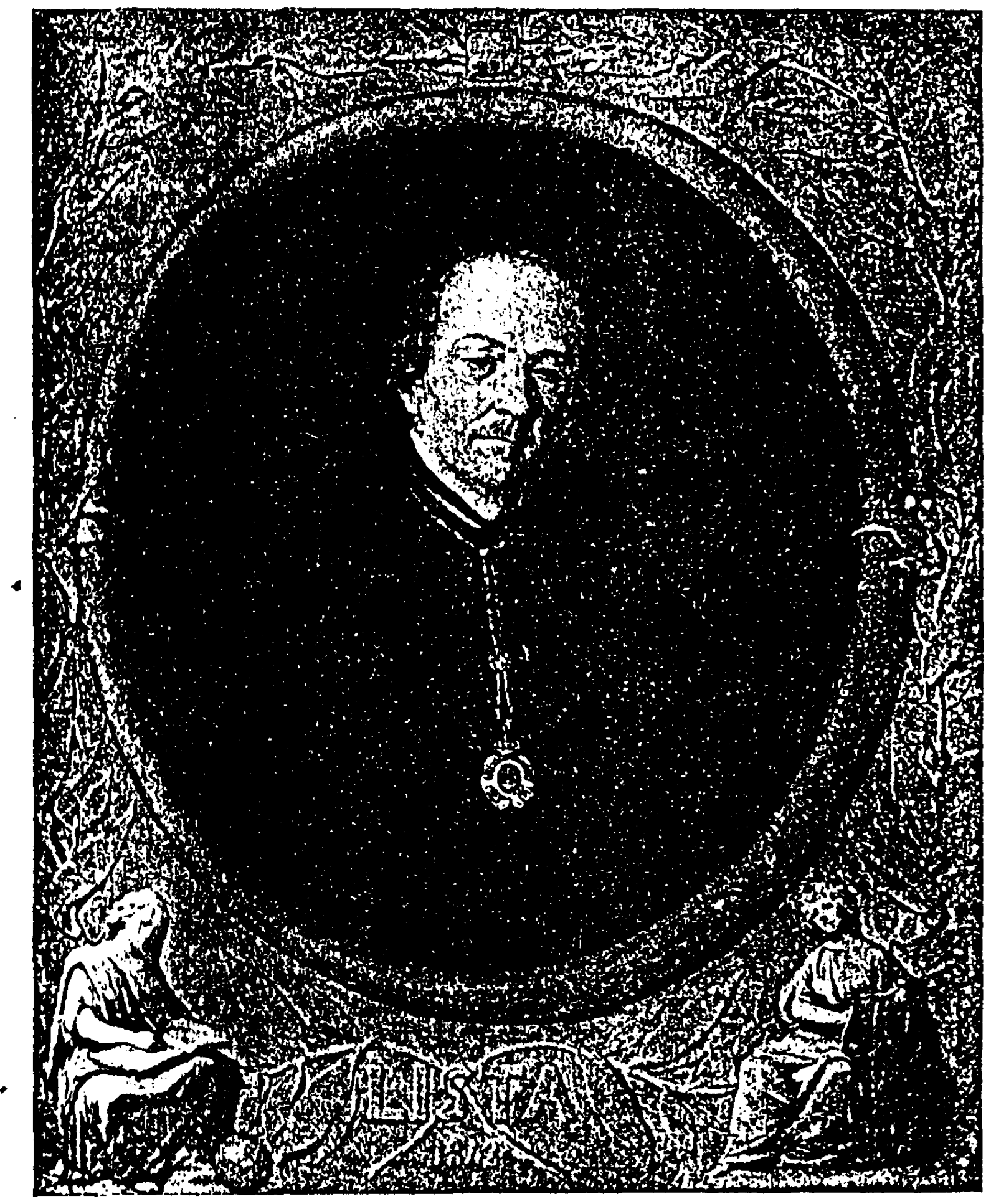

1. Alberto Lista y Aragun

Colegio de San Mateo A. I. Madrilenos 
ya que ocupaba la presidencia de la Academia de Bellas Artes y dirigía las obras de pintura en la restauración del Alcázar ${ }^{1}$. Nueve años más tarde, en febrero del 57 , Bécquer asciende a Numerario de Buenas Letras. A partir de este ascenso, acude puntualmente a las sesiones académicas, aunque no participa en las actividades de tipo literario. En I863 regala a la corporación un ejemplar de las Novclas cjemplarcs $y$ amorosas de Maria de Zayas y otro de las Noticias americanas, de Antonio Ulloa. Ein $x 87 \mathrm{I}$ la misma Academia le encarga los retratos de Tomás González Carvajal y de Donoso Cortés. No se sabe si llegó a pintar este último, pero sí consta en las actas que regaló el de González Carvajal.

Con estos datos, no recogidos por los biógrafos de Lista, pretendo contribuir al mejor conocimiento del pintor sevillano Joaquín Domfnguez. Bécquer, a cuyas paternales atenciones tanto clebió el Custavo Adolfo adolescente.

\section{IRRANCisco Agullar piñal.}

1 Véase: Josí Gurrrinko I,ovrilo, Los pintores románlicos sevillanos. Archivo Hispalense, 1949, núms. 36-37-38. 